\title{
Gene therapy by electroporation for the treatment of chronic renal failure in companion animals Patricia A Brown ${ }^{1}$, Angela M Bodles-Brakhop ${ }^{2}$, Melissa A Pope ${ }^{2}$ and Ruxandra Draghia-Akli*2
}

Address: ${ }^{1}$ VGX Animal Health, 2700 Research Forest Drive, Suite 180, The Woodlands, Texas 77381, USA and ${ }^{2}$ VGX Pharmaceuticals Inc., 2700 Research Forest Drive, Suite 180, The Woodlands, Texas 77381, USA

Email: Patricia A Brown - pbrown@vgxah.com; Angela M Bodles-Brakhop - abrakhop@vgxp.com; Melissa A Pope - mpope@vgxp.com; Ruxandra Draghia-Akli* - rdraghia@vgxp.com

* Corresponding author

Published: 16 January 2009

BMC Biotechnology 2009, 9:4 doi:10.1 186/1472-6750-9-4
Received: 8 October 2008

Accepted: 16 January 2009

This article is available from: http://www.biomedcentral.com/I472-6750/9/4

(C) 2009 Brown et al; licensee BioMed Central Ltd.

This is an Open Access article distributed under the terms of the Creative Commons Attribution License (http://creativecommons.org/licenses/by/2.0), which permits unrestricted use, distribution, and reproduction in any medium, provided the original work is properly cited.

\begin{abstract}
Background: Growth hormone-releasing hormone (GHRH) plasmid-based therapy for the treatment of chronic renal failure and its complications was examined. Companion dogs $(I 3.1 \pm 0.8$ years, $29.4 \pm 5.0 \mathrm{l} \mathrm{kg})$ and cats $(13.2 \pm 0.9$ years, $8.5 \pm 0.37 \mathrm{~kg})$ received a single $0.4 \mathrm{mg}$ or $0.1 \mathrm{mg}$ species-specific plasmid injection, respectively, intramuscularly followed by electroporation, and analyzed up to 75 days post-treatment; controls underwent electroporation without plasmid administration.
\end{abstract}

Results: Plasmid-treated animals showed an increase in body weight (dogs $22.5 \%$ and cats $3.2 \%$ ) compared to control animals, and displayed improved quality of life parameters including significant increases in appetite, activity, mentation and exercise tolerance levels. Insulin-like growth factor I (IGF-I, the downstream effector of GHRH) levels were increased in the plasmid treated animals. Hematological parameters were also significantly improved. Protein metabolism changes were observed suggesting a shift from a catabolic to an anabolic state in the treated animals. Blood urea nitrogen and creatinine did not show any significant changes suggesting maintenance of kidney function whereas the control animal's renal function deteriorated. Treated animals survived longer than control animals with $70 \%$ of dogs and $80 \%$ of cats surviving until study day 75 . Only $17 \%$ and $40 \%$ of the control dogs and cats, respectively, survived to day 75 .

Conclusion: Improved quality of life, survival and general well-being indicate that further investigation is warranted, and show the potential of a plasmid-based therapy by electroporation in preventing and managing complications of renal insufficiency.

\section{Background}

Renal failure and its complications, such as anemia and decreased life expectancy, can be related to primary kidney disease, such as glomerulonephritis or pyelonephritis, or are a consequence of long-term chronic diseases such as cancer, hypertension, heart failure, diabetes or severe allergic reactions $[1,2]$. The predicted increase in the number of people with renal failure and end-stage renal disease places an enormous burden on the healthcare provider system [3]. Strategies are therefore needed to improve the prevention, detection [4] and treatment of kidney disease. 
Chronic renal failure (CRF) can affect the growth hormone releasing hormone/growth hormone/insulin-like growth factor-I (GHRH/GH/IGF-I) axis [5] which can lead to growth retardation in children and is associated with increased morbidity and mortality [6,7]. The action of GH and its mediator, IGF-I, on body composition, protein, glucose, and bone metabolism offers real therapeutic options for these patients, including the improvement of the catabolic state in adults with end-stage renal failure. Recombinant human GH has been shown to be effective in promoting growth in children of short stature with CRF both prior to and following renal transplantation [8]. Wuhl and co-investigators showed that in a few pilot studies and two placebo-controlled studies of 6 months duration, GH treatment in adults on dialysis showed clear anabolic effects resulting in a significant increase in lean body mass [9]. However, existing treatments for conditions associated with renal failure, such as anemia, wasting, immune dysfunction, or other conditions have some significant drawbacks: the daily injection routine is impractical and often associated with local or systemic adverse effects and may lead to non-compliance in patients.

The technique of electroporation (EP) is an important development for gene therapeutic approaches with the potential to treat many conditions with a single low dose of plasmid resulting in long-term effects. Previous studies using GHRH showed that plasmid therapy with EP is scalable and represents a promising approach to induce production and regulated secretion of proteins in both large animal models and in humans [10-13]. Others have also reported successful EP-mediated gene therapy or DNA vaccination in large animals [14-16]. In this current open label pilot study we have analyzed the impact of the plasmid GHRH/EP approach to treat renal failure and its complications in affected companion animals (dogs and cats) as a model for human disease. This approach has proved successful in a Phase I veterinary trial where 9 dogs with malignant melanoma were successfully treated with a xenogeneic human tyrosinase DNA vaccination delivered by the Biojector 2000 jet delivery device [17]. Furthermore, the use of companion animals provides an important bridge between preclinical studies and clinical trials while providing important information for both veterinarians and researchers involved in the study of human disease and treatments. Our results show that this gene therapeutic approach by EP can treat some of the complications of kidney failure, while increasing the well being, quality of life and life expectancy of CRF animals.

\section{Results}

Sixty companion animals were enrolled in this pilot GHRH-study (30 cats and 30 dogs); an additional 27 were enrolled as control animals ( 15 cats and 12 dogs) (Table 1 ). No adverse effects of the plasmid administration were noted by the owners or the veterinarians caring for the animals. As this was a pilot study enlisting chronically ill companion animals, data at all time points was not available or collected due to owner compliance, especially for control animals, thus a statistical analysis was not performed for some of the parameters measured. The number of animals analyzed at each data point is specified in the cases where data from all animals was not available.

Treatment with GHRH led to an increase in survival. By day 75 , only $40 \%$ ( $n=6$ out of 15 ) of the control cats were still alive whereas $80 \%(n=24$ out of 30$)$ of the GHRHtreated cats survived; only $17 \%(n=2$ out of 12$)$ of the control dogs survived until day 75 whereas $70 \%(\mathrm{n}=21$ out of 30) of the GHRH-treated dogs survived.

Body weight increased for the GHRH-treated dogs. Body weight in GHRH-treated cats remained stable with only a slight increase (Table 2). For the GHRH-treated dogs, the initial average body weight was $29.44 \pm 5.01 \mathrm{~kg}(\mathrm{n}=27$, day 0$)$ and increased to $36.08 \pm 9.07 \mathrm{~kg}(P<0.05)$ by day $40(\mathrm{n}=21)$, an improvement of $22.5 \%$. The GHRHtreated cats body weight changed from $8.52 \pm 0.37 \mathrm{~kg}$ at day $0(\mathrm{n}=27)$ to $8.80 \pm 0.58 \mathrm{~kg}$ at day $40(\mathrm{n}=27)$, an improvement of $3.2 \%$. However, the control animals exhibited a reduction in body weight over the study period. The body weight of the control cats decreased from an initial average of $10.44 \pm 1.48 \mathrm{~kg}(\mathrm{n}=6)$ to 7.05 $\pm 0.23 \mathrm{~kg}$ and the control dogs weight decreased from an initial average of $15.95 \pm 4.84 \mathrm{~kg}(\mathrm{n}=4)$ to $11.09 \pm 3.05$ $\mathrm{kg}$ at day 20 . These control results were not statistically significant most likely due to the small number of companion animals that were able to be analyzed.

Quality of life (QOL) parameters were not individually tabulated for control animals, but overall the attending veterinarians noted stable to worsening performance. Assessment of QOL parameters as determined by the owner's for treated dogs and cats was collected from baseline to day 60 post-treatment, and is shown in Tables 3 and 4 respectively. The overall QOL significantly improved for treated dogs compared to baseline. In particular, for treated dogs activity and exercise levels significantly improved, and appetite and mentation improved. For treated cats, the overall QOL significantly improved throughout the duration of the study, in particular, activity, exercise, mentation and appetite. Importantly, these findings regarding the QOL are similar to previously published results for dogs with spontaneous malignancies that were treated with a GHRH-expressing plasmid [13].

Cats and dogs with CRF treated with plasmid-GHRH showed an increase in their IGF-I levels compared to their baseline. Significantly increased IGF-I levels throughout 
Table I: Dog and cat breeds and age at enrollment.

\begin{tabular}{|c|c|c|c|c|c|c|}
\hline Treated & Breed Dog & $\begin{array}{c}\text { Age at enrollment } \\
\text { (yrs) }\end{array}$ & $\begin{array}{c}\text { Weight at } \\
\text { enrollment (lbs) }\end{array}$ & Breed Cat & $\begin{array}{c}\text { Age at enrollment } \\
\text { (yrs) }\end{array}$ & $\begin{array}{c}\text { Weight at } \\
\text { enrollment (Ibs) }\end{array}$ \\
\hline TI & Poodle & 10.9 & 9.5 & DSH & 13.9 & 8.5 \\
\hline $\mathbf{T 2}$ & Shih Tzu & 6.2 & 6.62 & Calico & 17.8 & 9.75 \\
\hline T3 & Airedale & 8.9 & 65 & $\mathrm{DMH}$ & 15.0 & 6 \\
\hline T4 & Terrier Mix & 18.0 & $\mid 1.31$ & $\mathrm{DMH}$ & 15.1 & $|3.4|$ \\
\hline T5 & Bulldog & 1.6 & 66 & Bengal & 9.8 & 9.75 \\
\hline T6 & Greyhound & 11.9 & 62 & DSH & 13.1 & 7.5 \\
\hline T7 & Poodle & 15.7 & 6.25 & DSH & 17.9 & 6 \\
\hline T8 & Mixed & 17.1 & 18.4 & DSH & 1.0 & 9 \\
\hline T9 & Labrador & 17.2 & 48.2 & DSH & 17.1 & 6 \\
\hline TIO & Labrador & 9.7 & 65.7 & DLH & 14.1 & 7.69 \\
\hline TII & Greyhound & 19.1 & 51.3 & $\mathrm{DSH}$ & 19.1 & 10.53 \\
\hline TI2 & $\begin{array}{l}\text { West Highland } \\
\text { Terrier }\end{array}$ & 15.1 & 22 & Persian & 17.1 & 7.1 \\
\hline TI3 & Yorkshire Terrier & 13.7 & 10.8 & DLH & 6.4 & 10.5 \\
\hline TI4 & Yorkshire Terrier & 11.4 & 3.31 & DSH & 17.1 & 7.4 \\
\hline TI5 & Bichon Frise & 16.3 & 8.13 & DSH & I7.I & 8.06 \\
\hline T16 & Australian Shepherd & 15.2 & 29.06 & Persian & 19.1 & 5.88 \\
\hline TI7 & Pomeranian & 13.0 & 4.19 & DLH & 3.1 & 10.25 \\
\hline TI8 & Shih Tzu & 10.3 & 16.56 & Siamese & 2.1 & 9.75 \\
\hline T19 & Labrador & 9.1 & 78.6 & Himalayan & 6.1 & 8 \\
\hline $\mathbf{T 2 0}$ & Chihuahua & 16.6 & 4.31 & DSH & 12.1 & 7 \\
\hline T2I & Rat Terrier & 15.9 & 10 & DSH & 14.9 & 6 \\
\hline T22 & Cocker Spaniel & 10.8 & 27.4 & $\mathrm{DSH}$ & 15.9 & 7.13 \\
\hline T23 & Pomeranian & 12.8 & 4.8 & Siamese & 14.1 & 9.19 \\
\hline T24 & Terrier Mix & 15.2 & 29.9 & Siamese & 16.9 & 12 \\
\hline T25 & Terrier Mix & 13.8 & 13.5 & DSH & 13.2 & $\mid 1.31$ \\
\hline T26 & Terrier Mix & 19.3 & 17.75 & DLH & 14.5 & 8.31 \\
\hline T27 & German Shepherd & 6.9 & 68.4 & DSH & 11.2 & 6.4 \\
\hline T28 & Shih Tzu & 15.3 & 16 & Maine Coon & 15.2 & 7.12 \\
\hline T29 & Dachshund Mix & 16.9 & 7.3 & DSH & 11.2 & 8.88 \\
\hline T30 & Labrador & 10.0 & 101 & DSH & 14.2 & 11.25 \\
\hline Average & & $13.1 \pm 0.8$ & $29.44 \pm 5.01$ & & $13.2 \pm 0.9$ & $8.52 \pm 0.37$ \\
\hline Control & Breed Dog & $\begin{array}{c}\text { Age at enrollment } \\
\text { (yrs) }\end{array}$ & $\begin{array}{c}\text { Weight at } \\
\text { enrollment (lbs) }\end{array}$ & Breed Cat & $\begin{array}{c}\text { Age at enrollment } \\
\text { (yrs) }\end{array}$ & $\begin{array}{c}\text { Weight at } \\
\text { enrollment (Ibs) }\end{array}$ \\
\hline CI & Labrador & 13.92 & & DSH & 10.87 & \\
\hline C2 & Welsh Corgi & 10.15 & 28.6 & DSH & 7.04 & \\
\hline C3 & Maltese & 11.16 & 5 & DSH & 15.76 & 9.3 \\
\hline C4 & Shih Tzu & 10.00 & 15.2 & DSH & 13.68 & 9.94 \\
\hline C5 & Poodle & 13.75 & & DSH & 7.33 & 7.56 \\
\hline C6 & Yorkshire/Poodle & 14.54 & & Siamese & 14.44 & 11.69 \\
\hline $\mathrm{C7}$ & Lhasa apso & 15.84 & 15 & DLH & 18.59 & 7.12 \\
\hline C8 & Chihuahua/Terrier & 13.50 & & DLH & 12.36 & 17 \\
\hline C9 & Dalmatian & 10.66 & & Birman & 11.42 & \\
\hline CIO & Lhasa apso & 12.72 & & DLH & 16.88 & \\
\hline CII & Brussels Griffon & 12.79 & & DSH & 15.82 & \\
\hline $\mathrm{CI}$ & Am Eskimo & $|5.8|$ & & DSH & 14.85 & \\
\hline $\mathrm{CI3}$ & & & & Persian & 10.31 & \\
\hline CI4 & & & & DSH & 16.02 & \\
\hline CI5 & & & & DSH & 14.57 & \\
\hline Average & & $12.9 \pm 0.59$ & $\mid 5.95 \pm 4.84$ & & $13.33 \pm 0.87$ & $10.44 \pm 1.48$ \\
\hline
\end{tabular}


Table 2: Treated dog and cat average body weights during the study.

\begin{tabular}{|c|c|c|c|c|}
\hline & \multicolumn{4}{|c|}{ Treated dogs } \\
\hline & Day I & Day 20 & Day 40 & Day 60 \\
\hline Average weight (Ibs) \pm SEM & $29.44 \pm 5.01$ & $25.25 \pm 4.99$ & $36.08 \pm 9.07$ & $33.14 \pm 12.01$ \\
\hline$n$ & 30 & 22 & 10 & 6 \\
\hline Ttest, $P$ value & & & 0.046 & 0.166 \\
\hline \multirow[t]{3}{*}{$\%$ Change from day I } & & & 22.54 & 12.55 \\
\hline & \multicolumn{4}{|c|}{ Treated cats } \\
\hline & Day I & Day 20 & Day 40 & Day 60 \\
\hline Average weight (Ibs) \pm SEM & $8.52 \pm 0.37$ & $8.78 \pm 0.44$ & $8.80 \pm 0.58$ & $8.69 \pm 0.49$ \\
\hline$n$ & 30 & 22 & 14 & 10 \\
\hline Ttest, $P$ value & & 0.456 & 0.221 & 0.198 \\
\hline$\%$ Change from day I & & 2.97 & 3.24 & 1.99 \\
\hline
\end{tabular}

the study period were seen in $72 \%$ of dogs and $65 \%$ of cats $(P<0.05)$ when compared to day 0 (Figure 1$)$.

In GHRH injected cats and dogs, improvements in hematological parameters compared to controls were obtained as early as twenty days after the plasmid injection. Tables 5 and 6 show hematocrit (PCV), hemoglobin ( $\mathrm{Hb})$, red blood cell count (RBC), and mean red cell hemoglobin (MHC) in dogs and cats with CRF treated with plasmidmediated GHRH therapy, as well as control animals. Some disparities in response were observed between cats and dogs. This was most probably due to the heterogeneous nature of the groups, the relative moderate number of animals enrolled in the study and species differences. Percentage differences are indicated, with treated dogs showing significant changes up to $10.9 \%$ when compared to baseline levels that were below normal ranges. Hematological parameters for control dogs were stable throughout the study although a slight decrease was noted. Overall, the hematological parameters improved for the GHRH-treated animals, while remaining within or just below normal levels. Control animals displayed better hematological parameters at the time of enrollment compared to GHRH-treated animals. Increased circulating levels of iron were seen in the GHRH-treated dogs compared to baseline (Figure 2, $P<0.05$ ). No significant changes in circulating levels of iron were observed in the GHRHtreated cats.

Serum albumin and total protein values in cats and dogs with CRF were also measured. The analysis of serum albumin (normal range for cats 2.4-3.5 g/dl) for the GHRHtreated cats showed a $13 \%$ increase at 20 days post-treatment $(\mathrm{P}<0.001)$. In addition, total protein (normal range for cats $5.3-8.5 \mathrm{~g} / \mathrm{dl}$ ) in GHRH-treated cats increased $9 \%$ $(\mathrm{P}<0.001)$. These changes correlated with an improved protein metabolism, consistent with a change from a catabolic state to an anabolic state. Control cats did not significantly differ from day 0 (Figure 3). Minor increases were observed in the GHRH-treated dogs although these findings were not significant.

Blood urea nitrogen (BUN) and creatinine values (indicators of renal function) were examined in dogs and cats with CRF treated with plasmid-mediated GHRH therapy. Analysis of BUN levels for the GHRH-treated dogs showed a $17 \%$ reduction, and in concert a $16 \%$ decrease in creatinine levels, whereas in control dogs BUN and creatinine levels increased by day 75 compared to day 0 (Figure 4A \&4B). BUN/creatinine ratios in control cats increased from $18.15 \pm 1.58$ (day 0) to $20.46 \pm 2.26$ (day $75, P<$ $0.17)$, whereas the BUN/creatinine ratios in the GHRHtreated cats remained stable (Figure 4C). Overall kidney function was maintained in GHRH-treated dogs and cats whereas the controls demonstrated a trend towards deterioration of kidney function. All other parameters measured did not change significantly.

\section{Discussion}

At present there are approximately 30 million American's affected by chronic kidney disease, with an estimated 2.2 million requiring treatment for end-stage renal disease by 2030, greatly impacting the healthcare system [18]. Malnutrition and wasting are important determinants of morbidity and mortality in patients with CRF on dialysis. Even patients with a relatively modest degree of chronic renal insufficiency are characterized by reduced lean body mass, bone mineral content, and basal energy expenditure [19]. In humans CRF has been linked to a high prevalence of anemia in an elderly population (64.9\% with vs. $55.7 \%$ without CRF) with the greater risk of anemia in the presence of CRF increasing with age [20]. Most cases of CRF are associated with aging and it is one of the most common illnesses of geriatric cats and dogs [21]. Approximately one in five cats over the age of 15 yrs has CRF and it is estimated to occur 3 times more frequent in cats than dogs. 
Table 3: Quality of life assessment for GHRH-treated dogs.

\begin{tabular}{|c|c|c|c|c|c|}
\hline \multicolumn{2}{|l|}{ Assessment } & \multirow{2}{*}{$\begin{array}{c}\text { Day 0 } \\
\begin{array}{c}3.08 \pm 0.05 \\
n=26\end{array}\end{array}$} & \multirow{2}{*}{$\begin{array}{c}\text { Day } 20 \\
3.43 \pm 0.18 * \\
n=23 \\
11.63 \% \\
0.06\end{array}$} & \multirow{2}{*}{$\begin{array}{c}\text { Day } 40 \\
3.39 \pm 0.20 \\
n=18 \\
10.14 \% \\
0.10\end{array}$} & \multirow{2}{*}{$\begin{array}{c}\text { Day } 60 \\
3.71 \pm 0.17 \\
n=17 \\
20.44 \% \\
0.0005\end{array}$} \\
\hline Overall QOL & $\begin{array}{c}\text { Average score } \\
n \\
\% \text { change } \\
P \text {-value vs. Day } 0\end{array}$ & & & & \\
\hline Body Weight & $\begin{array}{c}\text { Average score } \\
n \\
\% \text { change } \\
P \text {-value vs. Day } 0\end{array}$ & $\begin{array}{c}3.0 \pm 0.0 \\
n=28\end{array}$ & $\begin{array}{c}3.0 \pm 0.11 \\
n=19 \\
0.0 \% \\
0.5\end{array}$ & $\begin{array}{c}3.13 \pm 0.20 \\
n=16 \\
4.17 \% \\
0.27\end{array}$ & $\begin{array}{c}3.18 \pm 0.15 \\
n=17 \\
5.88 \% \\
0.14\end{array}$ \\
\hline Activity Level & $\begin{array}{c}\text { Average score } \\
n \\
\% \text { change } \\
P \text {-value vs. Day } 0\end{array}$ & $\begin{array}{c}2.97 \pm 0.08 \\
n=29\end{array}$ & $\begin{array}{c}3.52 \pm 0.19 \\
n=23 \\
18.76 \% \\
0.02\end{array}$ & $\begin{array}{c}3.32 \pm 0.19 \\
n=22 \\
I 1.89 \% \\
0.03\end{array}$ & $\begin{array}{c}3.67 \pm 0.14 \\
n=18 \\
23.64 \% \\
0.0001\end{array}$ \\
\hline Exercise Tolerance & $\begin{array}{c}\text { Average score } \\
n \\
\% \text { change } \\
\text { P-value vs. Day } 0\end{array}$ & $\begin{array}{c}3.07 \pm 0.07 \\
n=29\end{array}$ & $\begin{array}{c}3.21 \pm 0.14 \\
n=23 \\
4.84 \% \\
0.19\end{array}$ & $\begin{array}{c}3.32 \pm 0.19 \\
n=22 \\
8.12 \% \\
0.10\end{array}$ & $\begin{array}{c}3.72 \pm 0.16 \\
n=18 \\
21.29 \% \\
0.0003\end{array}$ \\
\hline Mentation & $\begin{array}{c}\text { Average score } \\
n \\
\% \text { change } \\
\text { P-value vs. Day } 0\end{array}$ & $\begin{array}{c}3.14 \pm 0.08 \\
n=29\end{array}$ & $\begin{array}{c}3.43 \pm 0.15 \\
n=23 \\
9.46 \% \\
0.10\end{array}$ & $\begin{array}{c}3.14 \pm 0.20 \\
n=21 \\
0.16 \% \\
0.5\end{array}$ & $\begin{array}{c}3.47 \pm 0.18 \\
n=17 \\
10.60 \% \\
0.052\end{array}$ \\
\hline Appetite & $\begin{array}{c}\text { Average score } \\
n \\
\% \text { change } \\
\text { P-value vs. Day } 0\end{array}$ & $\begin{array}{c}2.98 \pm 0.07 \\
n=29\end{array}$ & $\begin{array}{c}3.48 \pm 0.19 \\
n=23 \\
16.61 \% \\
0.01\end{array}$ & $\begin{array}{c}3.19 \pm 0.21 \\
\mathrm{n}=21 \\
6.96 \% \\
0.24\end{array}$ & $\begin{array}{c}3.24 \pm 0.18 \\
n=17 \\
8.47 \% \\
0.07\end{array}$ \\
\hline Thirst & $\begin{array}{c}\text { Average score } \\
n \\
\% \text { change } \\
\text { P-value vs. Day } 0\end{array}$ & $\begin{array}{c}3.0 \pm 0.0 \\
n=29\end{array}$ & $\begin{array}{c}3.13 \pm 0.14 \\
\mathrm{n}=23 \\
4.35 \\
0.19\end{array}$ & $\begin{array}{c}3.05 \pm 0.15 \\
n=21 \\
1.56 \% \\
0.37\end{array}$ & $\begin{array}{c}3.0 \pm 0.08 \\
\mathrm{n}=18 \\
0 \% \\
0.5\end{array}$ \\
\hline Urination Frequency & $\begin{array}{c}\text { Average score } \\
n \\
\% \text { change } \\
P \text {-value vs. Day } 0\end{array}$ & $\begin{array}{c}3.0 \pm 0.0 \\
n=29\end{array}$ & $\begin{array}{c}3.04 \pm 0.13 \\
\mathrm{n}=23 \\
1.45 \% \\
0.37\end{array}$ & $\begin{array}{c}2.95 \pm 0.11 \\
n=21 \\
-1.59 \% \\
0.33\end{array}$ & $\begin{array}{c}3.11 \pm 0.08 \\
n=18 \\
3.70 \% \\
0.08\end{array}$ \\
\hline Bowel Movement Frequency & $\begin{array}{c}\text { Average score } \\
\text { n } \\
\% \text { change } \\
\text { P-value vs. Day } 0\end{array}$ & $\begin{array}{c}3.04 \pm 0.04 \\
n=28\end{array}$ & $\begin{array}{c}3.09 \pm 0.15 \\
n=23 \\
1.69 \% \\
0.29\end{array}$ & $\begin{array}{c}3.0 \pm 0.12 \\
\mathrm{n}=21 \\
-1.18 \% \\
0.5\end{array}$ & $\begin{array}{c}3.0 \pm 0.0 \\
n=18 \\
-1.18 \% \\
N S\end{array}$ \\
\hline Diarrhea Frequency & $\begin{array}{c}\text { Average score } \\
n \\
\% \text { change } \\
\text { P-value vs. Day } 0\end{array}$ & $\begin{array}{c}3.10 \pm 0.06 \\
n=29\end{array}$ & $\begin{array}{c}3.0 \pm 0.0 \\
n=23 \\
-3.33 \% \\
\text { NS }\end{array}$ & $\begin{array}{c}3.05 \pm 0.05 \\
n=21 \\
-1.80 \% \\
0.16\end{array}$ & $\begin{array}{c}3.0 \pm 0.0 \\
n=18 \\
-3.33 \% \\
0.17\end{array}$ \\
\hline Vomiting Frequency & $\begin{array}{c}\text { Average score } \\
n \\
\% \text { change } \\
\text { P-value vs. Day } 0\end{array}$ & $\begin{array}{c}3.07 \pm 0.05 \\
n=29\end{array}$ & $\begin{array}{c}2.96 \pm 0.04 \\
n=23 \\
-3.66 \% \\
0.04\end{array}$ & $\begin{array}{c}3.05 \pm 0.05 \\
n=21 \\
-0.70 \% \\
0.29\end{array}$ & $\begin{array}{c}3.03 \pm 0.03 \\
n=18 \\
-1.34 \% \\
0.09\end{array}$ \\
\hline
\end{tabular}

Abbreviations: NS, not significant Quality of life parameters from day 0 to day 60 of study where $\mathrm{I}=$ significantly decreased, $2=$ decreased, $3=$ no change, $4=$ increased and $5=$ significantly increased. For each parameter, data are presented as average \pm SEM. Percentage changes over baseline values, as well as $P$ value versus baseline values is included for each parameter at each time point.

As CRF has limited therapeutic options for both humans and pets any adjuvant therapy that delays associated disorders in these patients is of high interest. Unfortunately, the lack of efficient drug therapy for supporting CRF patients significantly increases their morbidity and mortality [22]. Currently, chronic dialysis or kidney transplant are the most common forms of treatment for humans. For pets, most studies focus on nutrition and dietary changes as the only available existing therapy [23]. It has been previously shown that the administration of a GHRH-analog had also an immune-enhancing effect on healthy aging individuals through stimulation of the GHRH/GH/IGF-I axis [24]. Administration of GHRH to CRF patients may improve their quality of life by acting as an immuneenhancing agent and treating their anemia. Here we show that a one-time treatment with a plasmid expressing GHRH followed by EP can improve the outcome of companion animals with renal insufficiency.

In this open label study we have enrolled companion animals for testing of a plasmid-mediated GHRH gene therapy in a heterogeneous animal population that is more 
Table 4: Quality of life assessment for GHRH-treated cats.

\begin{tabular}{|c|c|c|c|c|c|}
\hline Assessment & & Day 0 & Day 20 & Day 40 & Day 60 \\
\hline Overall QOL & $\begin{array}{c}\text { Average score } \\
n \\
\% \text { change } \\
P \text {-value vs. Day } 0\end{array}$ & $\begin{array}{c}3.0 \pm 0.05 \\
n=28\end{array}$ & $\begin{array}{c}3.36 \pm 0.1 I \\
n=25 \\
I 2.0 \% \\
0.008\end{array}$ & $\begin{array}{c}3.43 \pm 0.14 \\
n=22 \\
14.39 \\
0.001\end{array}$ & $\begin{array}{c}3.68 \pm 0.19 \\
n=19 \\
22.81 \% \\
0.0009\end{array}$ \\
\hline Body Weight & $\begin{array}{c}\text { Average score } \\
n \\
\% \text { change } \\
P \text {-value vs. Day } 0\end{array}$ & $\begin{array}{c}3.0 \pm 0.0 \\
n=28\end{array}$ & $\begin{array}{c}3.0 \pm 0.11 \\
n=18 \\
0.0 \% \\
0.5\end{array}$ & $\begin{array}{c}3.36 \pm 0.17 \\
n=14 \\
11.9 \% \\
0.03\end{array}$ & $\begin{array}{c}3.18 \pm 0.21 \\
\mathrm{n}=17 \\
5.88 \% \\
0.21\end{array}$ \\
\hline Activity Level & $\begin{array}{c}\text { Average score } \\
n \\
\% \text { change } \\
\text { P-value vs. Day } 0\end{array}$ & $\begin{array}{c}3.07 \pm 0.10 \\
n=28\end{array}$ & $\begin{array}{c}3.27 \pm 0.13 \\
n=26 \\
6.44 \% \\
0.13\end{array}$ & $\begin{array}{c}3.66 \pm 0.16 \\
n=22 \\
19.13 \% \\
0.002\end{array}$ & $\begin{array}{c}3.68 \pm 0.19 \\
n=19 \\
19.95 \% \\
0.005\end{array}$ \\
\hline Exercise Tolerance & $\begin{array}{c}\text { Average score } \\
n \\
\% \text { change } \\
P \text {-value vs. Day } 0\end{array}$ & $\begin{array}{c}3.0 \pm 0.05 \\
n=28\end{array}$ & $\begin{array}{c}3.23 \pm 0.08 \\
n=26 \\
7.69 \% \\
\mathbf{0 . 0 2}\end{array}$ & $\begin{array}{c}3.26 \pm 0.16 \\
n=21 \\
8.73 \% \\
0.06\end{array}$ & $\begin{array}{c}3.61 \pm 0.18 \\
n=18 \\
20.37 \% \\
0.002\end{array}$ \\
\hline Mentation & $\begin{array}{c}\text { Average score } \\
n \\
\% \text { change } \\
\text { P-value vs. Day } 0\end{array}$ & $\begin{array}{c}3.0 \pm 0.09 \\
n=28\end{array}$ & $\begin{array}{c}3.46 \pm 0.10 \\
n=26 \\
15.38 \% \\
\mathbf{0 . 0 0 2}\end{array}$ & $\begin{array}{c}3.38 \pm 0.15 \\
\mathrm{n}=21 \\
12.7 \% \\
\mathbf{0 . 0 0 8}\end{array}$ & $\begin{array}{c}3.45 \pm 0.14 \\
n=19 \\
14.91 \% \\
0.005\end{array}$ \\
\hline Appetite & $\begin{array}{c}\text { Average score } \\
n \\
\% \text { change } \\
\text { P-value vs. Day } 0\end{array}$ & $\begin{array}{c}3.07 \pm 0.11 \\
n=28\end{array}$ & $\begin{array}{c}3.15 \pm 0.16 \\
n=26 \\
2.68 \% \\
0.26\end{array}$ & $\begin{array}{c}3.23 \pm 0.16 \\
\mathrm{n}=22 \\
5.07 \% \\
0.10\end{array}$ & $\begin{array}{c}3.26 \pm 0.13 \\
n=19 \\
6.24 \% \\
0.04\end{array}$ \\
\hline Thirst & $\begin{array}{c}\text { Average score } \\
n \\
\% \text { change } \\
P \text {-value vs. Day } 0\end{array}$ & $\begin{array}{c}3.07 \pm 0.07 \\
n=28\end{array}$ & $\begin{array}{c}3.12 \pm 0.08 \\
\mathrm{n}=26 \\
1.43 \% \\
0.36\end{array}$ & $\begin{array}{c}3.19 \pm 0.13 \\
\mathrm{n}=21 \\
3.88 \% \\
0.27\end{array}$ & $\begin{array}{c}3.0 \pm 0.08 \\
n=19 \\
-2.33 \% \\
0.36\end{array}$ \\
\hline Urination Frequency & $\begin{array}{c}\text { Average score } \\
n \\
\% \text { change } \\
\text { P-value vs. Day } 0\end{array}$ & $\begin{array}{c}3.04 \pm 0.06 \\
n=28\end{array}$ & $\begin{array}{c}3.08 \pm 0.08 \\
n=26 \\
1.36 \% \\
0.36\end{array}$ & $\begin{array}{c}3.05 \pm 0.05 \\
\mathrm{n}=22 \\
0.32 \% \\
0.5\end{array}$ & $\begin{array}{c}3.0 \pm 0.0 \\
n=19 \\
-1.17 \% \\
0.29\end{array}$ \\
\hline Bowel Movement Frequency & $\begin{array}{c}\text { Average score } \\
n \\
\% \text { change } \\
P \text {-value vs. Day } 0\end{array}$ & $\begin{array}{c}2.93 \pm 0.05 \\
n=28\end{array}$ & $\begin{array}{c}2.92 \pm 0.09 \\
n=26 \\
-0.19 \% \\
0.5\end{array}$ & $\begin{array}{c}3.0 \pm 0.0 \\
n=22 \\
2.44 \% \\
0.08\end{array}$ & $\begin{array}{c}3.0 \pm 0.0 \\
\mathrm{n}=19 \\
2.44 \% \\
0.08\end{array}$ \\
\hline Diarrhea Frequency & $\begin{array}{c}\text { Average score } \\
n \\
\% \text { change } \\
\text { P-value vs. Day } 0\end{array}$ & $\begin{array}{c}3.0 \pm 0.0 \\
n=28\end{array}$ & $\begin{array}{c}3.04 \pm 0.07 \\
n=26 \\
I .28 \% \\
0.29\end{array}$ & $\begin{array}{c}3.0 \pm 0.0 \\
\mathrm{n}=22 \\
0.0 \% \\
\text { NS }\end{array}$ & $\begin{array}{c}3.0 \pm 0.0 \\
n=19 \\
0.0 \% \\
\text { NS }\end{array}$ \\
\hline Vomiting Frequency & $\begin{array}{c}\text { Average score } \\
n \\
\% \text { change } \\
P \text {-value vs. Day } 0\end{array}$ & $\begin{array}{c}3.07 \pm 0.05 \\
n=28\end{array}$ & $\begin{array}{c}3.04 \pm 0.07 \\
n=26 \\
-1.07 \% \\
0.33\end{array}$ & $\begin{array}{c}3.0 \pm 0.0 \\
n=22 \\
-2.33 \% \\
0.08\end{array}$ & $\begin{array}{c}3.05 \pm 0.05 \\
n=19 \\
-0.61 \% \\
0.29\end{array}$ \\
\hline
\end{tabular}

Abbreviations: NS, not significant Quality of life parameters from day 0 to day 60 of study where $\mathrm{I}=$ significantly decreased, $2=$ decreased, $3=$ no change, $4=$ increased and $5=$ significantly increased. For each parameter, data are presented as average \pm SEM. Percentage changes over baseline values, as well as $P$ value versus baseline values is included for each parameter at each time point.

representative of a human heterogeneous population than small laboratory animals. Not only does the use of companion animals provide important relevant information for the design and follow-up of future clinical studies, but will also allow the faster development of therapies for veterinary use. It is known that GHRH stimulates the GH and further the IGF-I axis during a catabolic state, which in turn stimulates erythropoiesis [25]. IGF-I counteracts apoptosis similarly to erythropoietin, and fosters proliferation of burst- and colony-forming units-erythroid [26]. Erythropoietic agents improve survival of CRF patients, and here we have shown that a similar benefit should apply for strategies that increase synthesis and bioavailability of IGF-I. Nevertheless, it is known that erythrocytes of patients suffering from CRF are exposed to an increased activity of free radicals, which leads to a decrease of erythrocytes' stability and a lower resistance to hemolysis. The intensity of changes is often according to the stage of the disease and the efficiency of treatment. It is possible that while the GHRH-treatment improves hematological parameters and stabilizes renal function, these changes are not sufficiently maintained long-term. This short-term correction phenomenon has been previously observed in both cats and dogs with CRF on erytopoietin treatment 

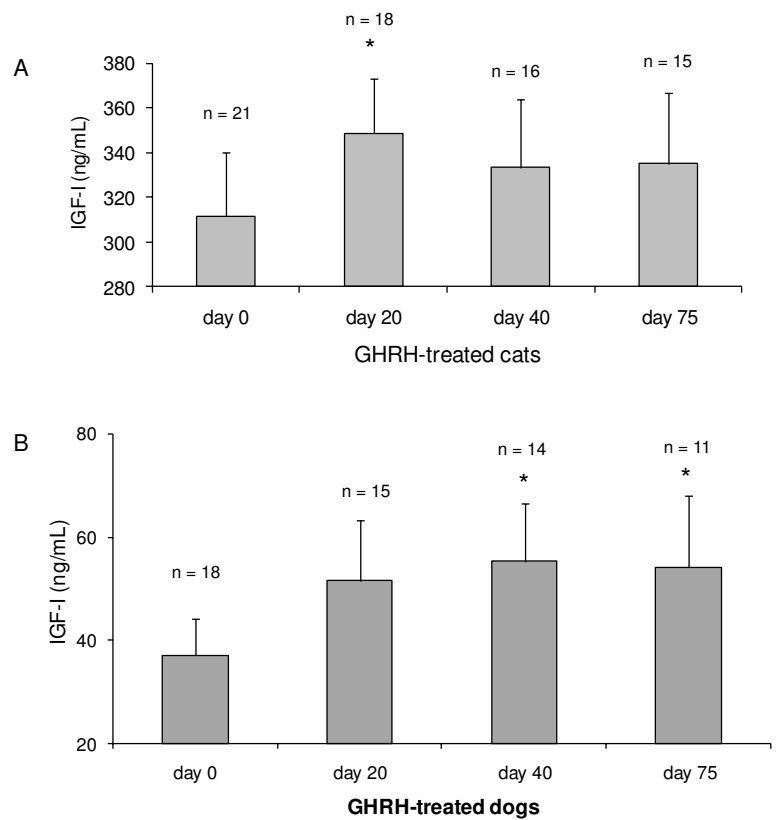

Figure I

IGF-I levels in cats and dogs with chronic renal failure treated with plasmid-mediated GHRH therapy. The results are presented as means \pm SEM. (A). $75 \%$ of GHRHtreated cats have increased IGF-I levels at 20-75 days after GHRH treatment $(* P<0.05)$. (B). $75 \%$ of GHRH-treated dogs have increased IGF-I levels at 20-75 days after GHRH treatment $(* P<0.05)$.

$[27,28]$. A follow up study will look at the possibility of plasmid re-administration, and long-term effects of the therapy. In this study, we also found that circulating iron levels were increased in the treated patients, supporting the hypothesis that the treatment may increase iron absorption; this hypothesis will be tested in future studies. Iron deficiency is often seen in CRF and is a common cause of anemia [29]; therefore treatment with GHRH may increase iron levels without the adverse effects of parenteral iron therapy [30]. Our previous studies supported the hypothesis that an increase in GHRH will positively impact renal function, anemia, and immune dysfunction, as well as reverse wasting, and extend life expectancy of chronically ill patients. Currently, GHRH, GH or IGF-I or their functional biological equivalents are used as recombinant proteins in the treatment or management of renal failure and impaired growth that is associated with this condition. Nonetheless, the necessity for daily injections of GH [31] or other recombinant proteins is a limiting factor as the patient's (or patient's owner's) compliance is typically low and can result in sub-optimal treatment outcomes.
The technique of EP is a significant development for the field of gene therapy, given the ability to administer small amounts of plasmid in a single dose with significant effect $[32,33]$. Previous studies have shown that injection alone of plasmid DNA results in relatively low uptake and expression levels in comparison to injection in conjunction with EP [34], which can increase expression by up to 100 fold [35]. The use of EP along with optimization of plasmid DNA for gene delivery or DNA vaccines has become more popular as the parameters for successful delivery without tissue damage have been elucidated [36], while expression and immunogeneicity increased by 100 to 1000 fold [37].

In larger animals, we have previously shown that GHRH treatment followed by EP can dramatically improve the conditions for companion animals with cancer, resulting in an extended life span with a greatly improved quality of life [13]. Hematological parameters were also significantly improved in the GHRH-treated dogs, reversing the cancer-associated anemia. Further studies have also shown the effectiveness of GHRH treatment in combination with EP. Treatment of horses with laminitis, an arthritic-like condition, reduced inflammation, and increased survival [12]. We have previously discussed [11] and experimentally shown [38] that it is not the injection and/or the EP that determines these responses, but the effects of GHRH expression after plasmid administration. The similarity of the response across species (rats, pigs, dogs and dairy cattle) suggests that the physiologic stimulation of the GHRH axis is a fundamental component of developmental physiology. Currently, DNA vaccines or therapeutic plasmids and EP are being tested in humans in a number of Phase I or I/II clinical trials (reviewed in [39-41]).

In animal models, EP has been shown to increase the efficiency of erythropoietin (Epo) gene transfer for the treatment of CRF-associated anemia [42]. In mice and rats, treatment of severe anemia associated with CRF with Epogene electrotransfer, where hematocrit levels were similar to those in humans with end-stage renal disease, resulted in increased Epo and hematocrit levels [43,44]. EP also increased the transduction of optimized Epo genes reducing inter-individual and species variability [45]. We are aware of studies that have intramuscularly delivered an Epo cDNA via recombinant adeno-associated virus in monkeys and cats leading to responses against endogenous Epo [46]; nevertheless, this seems to not be the case for GHRH. We have extensively used species-specific GHRH plasmids in many models including large animals, such as pigs. In one study, we attempted to measured antiGHRH antibodies, and no antibodies were detected 
Table 5: Hematological parameters in plasmid-GHRH treated dogs with CRF.

\begin{tabular}{|c|c|c|c|c|c|c|}
\hline \multicolumn{3}{|c|}{ Assessment } & \multirow{2}{*}{$\begin{array}{c}\text { Red Blood } \\
\text { Cells } \\
\begin{array}{c}6.29 \pm 0.5 \\
n=9\end{array}\end{array}$} & \multirow{2}{*}{$\begin{array}{l}\text { Hematocrit } \\
\begin{array}{c}39.98 \pm 2.6 \\
n=12\end{array}\end{array}$} & \multirow{2}{*}{$\begin{array}{l}\text { Hemoglobin } \\
\begin{array}{c}13.73 \pm 1.0 \\
n=12\end{array}\end{array}$} & \multirow{2}{*}{$\begin{array}{l}\text { Mean Red Cell Hemoglobin } \\
\qquad \begin{array}{c}23.13 \pm 0.8 \\
n=10\end{array}\end{array}$} \\
\hline Control & Day 0 & $\begin{array}{c}\text { Average score } \\
\mathrm{n}\end{array}$ & & & & \\
\hline & Day 20 & $\begin{array}{c}\text { Average score } \\
\% \text { change } \\
P \text {-value vs. Day } 0\end{array}$ & $\begin{array}{c}6.43 \pm 0.5 \\
2.2 \% \\
P<0.4 \\
n=6\end{array}$ & $\begin{array}{c}39.42 \pm 1.4 \\
-1.4 \% \\
P<0.2 \\
n=9\end{array}$ & $\begin{array}{c}13.89 \pm 0.8 \\
1.1 \% \\
P<0.2 \\
n=7\end{array}$ & $\begin{array}{c}22.62 \pm 0.7 \\
-2.2 \% \\
P<0.05 \\
\mathrm{n}=6\end{array}$ \\
\hline & Day 40 & $\begin{array}{c}\text { Average score } \\
\% \text { change } \\
P \text {-value vs. Day } 0\end{array}$ & $\begin{array}{c}5.53 \pm 0.4 \\
-12 \% \\
P<0.3 \\
n=6\end{array}$ & $\begin{array}{c}37.82 \pm 2.2 \\
-5.4 \% \\
P<0.3 \\
n=6\end{array}$ & $\begin{array}{c}12.8 \pm 1.0 \\
-7.0 \% \\
P<0.4 \\
n=6\end{array}$ & $\begin{array}{c}23.08 \pm 1.1 \\
-0.2 \% \\
P<0.26 \\
n=6\end{array}$ \\
\hline & Day 60-75 & $\begin{array}{c}\text { Average score } \\
\% \text { change } \\
P \text {-value vs. Day } 0\end{array}$ & $\begin{array}{c}5.69 \pm 0.2 \\
-10.0 \% \\
P<0.5 \\
n=2\end{array}$ & $\begin{array}{c}39.75 \pm 1.2 \\
-0.6 \% \\
P<0.5 \\
n=2\end{array}$ & $\begin{array}{l}12.1 \pm 2.2 \\
-12.0 \% \\
P<0.5 \\
n=2\end{array}$ & $\begin{array}{c}21.1 \pm 3.1 \\
-8.8 \% \\
P<0.19 \\
n=2\end{array}$ \\
\hline \multirow[t]{4}{*}{ Treated } & Day 0 & $\begin{array}{c}\text { Average score } \\
\mathrm{n}\end{array}$ & $\begin{array}{c}4.84 \pm 0.3 \\
n=30\end{array}$ & $\begin{array}{c}34.95 \pm 1.9 \\
n=30\end{array}$ & $\begin{array}{c}11.48 \pm 0.6 \\
n=30\end{array}$ & $\begin{array}{c}23.88 \pm 0.2 \\
n=30\end{array}$ \\
\hline & Day 20 & $\begin{array}{c}\text { Average score } \\
\% \text { change } \\
P \text {-value vs. Day } 0\end{array}$ & $\begin{array}{c}5.26 \pm 0.3 \\
8.6 \% \\
P<0.02 \\
\mathrm{n}=27\end{array}$ & $\begin{array}{l}37.4 \pm 1.8 \\
7.0 \% \\
P<0.1 \\
n=27\end{array}$ & $\begin{array}{c}12.74 \pm 0.6 \\
10.9 \% \\
P<0.01 \\
\mathrm{n}=27\end{array}$ & $\begin{array}{c}24.39 \pm 0.3 \\
2.1 \% \\
P<0.02 \\
n=27\end{array}$ \\
\hline & Day 40 & $\begin{array}{c}\text { Average score } \\
\% \text { change } \\
P \text {-value vs. Day } 0\end{array}$ & $\begin{array}{c}5.13 \pm 0.3 \\
5.9 \% \\
P<0.09 \\
\mathrm{n}=26\end{array}$ & $\begin{array}{c}36.73 \pm 2.1 \\
5.1 \% \\
P<0.21 \\
n=26\end{array}$ & $\begin{array}{c}12.53 \pm 0.6 \\
9.1 \% \\
P<0.01 \\
n=26\end{array}$ & $\begin{array}{c}24.58 \pm 0.3 \\
2.9 \% \\
P<0.001 \\
n=26\end{array}$ \\
\hline & Day 60-75 & $\begin{array}{c}\text { Average score } \\
\% \text { change } \\
P \text {-value vs. Day } 0\end{array}$ & $\begin{array}{c}5.19 \pm 0.3 \\
7.1 \% \\
P<0.15 \\
n=20\end{array}$ & $\begin{array}{c}37.07 \pm 2.2 \\
6 \% \\
P<0.25 \\
n=20\end{array}$ & $\begin{array}{c}12.69 \pm 0.8 \\
9.1 \% \\
P<0.02 \\
n=20\end{array}$ & $\begin{array}{c}24.31 \pm 0.4 \\
1.8 \% \\
P<0.1 \\
n=19\end{array}$ \\
\hline
\end{tabular}

Hematological parameters are significantly improved with plasmid treatment compared to day 0 . For dogs normal RBC $5.5-8.5 \times 10^{6} / \mathrm{mm}^{3} ; \mathrm{normal}$ $\mathrm{Ht} 37-55 \%$; and normal $\mathrm{Hb} 12-18 \mathrm{~g} / \mathrm{dl}$.

against the species-specific muscle-produced GHRH [47]. Although Epo treatment is an important therapeutic strategy for renal patients with anemia, the ability to treat more than one of CRF's related complications with a single therapeutic option is of great interest. The results of this study indicated that EP of plasmid GHRH may be such a solution, and an efficient and effective way to impact many of the complications in chronically ill patients.

\section{Conclusion}

As little as 0.1-0.4 mg of the GHRH therapeutic plasmid (equivalent to $11-13 \mu \mathrm{g} / \mathrm{kg}$ ) delivered under the proper EP conditions in a single injection has an important biological impact by physiologically increasing IGF-I levels, that stabilizes or improves kidney function and anemia, has the ability to reverse wasting, and extend life in ailing feline or canine subjects. The treated pets display increased activity and appetite, with an increase in body weight and overall improved health and survival rate. Health-related quality of life is increasingly recognized as an important outcome in clinical research and patient care. Significant impairment in health-related quality of life is seen with renal insufficiency, due to anemia, wast- ing, and other complications of chronic disease or aging. Results from these studies suggest that a clinical intervention such as EP of plasmid GHRH could preserve renal function and possibly improve the negative impact of kidney disease on health-related quality of life.

\section{Methods \\ Animals}

All experiments were carried out according to NIH regulations and the National Research Councils Guide for the Care and Use of Animals, and with the specific approval of the veterinarian clinics and the attending veterinarian for each companion animal. To qualify for this study, all companion animals must have had a confirmed diagnosis of CRF from a licensed veterinarian, met eligibility requirements, and have had the owner's written consent. Patients from 11 different veterinary practices in the Houston, TX area participated in this studies. Diagnosis of renal insufficiency by the animal's veterinarian was based on physical examination, and biochemical and urinalysis parameters (underlying conditions, including possible causes of CRF, were not determined or recorded by the attending veterinarian in a majority of cases). Prior to the plasmid treatment, animals were treated with fluids (e.g. 
Table 6: Hematological parameters in plasmid-GHRH treated cats with CRF.

\begin{tabular}{|c|c|c|c|c|c|c|}
\hline \multicolumn{3}{|c|}{ Assessment } & \multirow{2}{*}{$\begin{array}{c}\text { Red Blood } \\
\text { Cells } \\
\begin{array}{c}7.19 \pm .4 \\
\mathrm{n}=12\end{array}\end{array}$} & \multirow{2}{*}{$\begin{array}{l}\text { Hematocrit } \\
\begin{array}{c}31.68 \pm 1.5 \\
n=13\end{array}\end{array}$} & \multirow{2}{*}{$\begin{array}{l}\text { Hemoglobin } \\
\begin{array}{c}11.02 \pm .5 \\
n=12\end{array}\end{array}$} & \multirow{2}{*}{$\begin{array}{l}\text { Mean Red Cell Hemoglobin } \\
\qquad \begin{array}{c}15.44 \pm .4 \\
\mathrm{n}=12\end{array}\end{array}$} \\
\hline Control & Day 0 & $\begin{array}{c}\text { Average score } \\
\mathrm{n}\end{array}$ & & & & \\
\hline & Day 20 & $\begin{array}{c}\text { Average score } \\
\% \text { change } \\
P \text {-value vs. Day } 0\end{array}$ & $\begin{array}{l}7.72 \pm .5 \\
7.3 \% \\
P<0.16 \\
n=7\end{array}$ & $\begin{array}{c}32.87 \pm 2.0 \\
3.8 \% \\
P<0.30 \\
n=10\end{array}$ & $\begin{array}{c}10.75 \pm .8 \\
-2.0 \% \\
P<0.35 \\
\mathrm{n}=8\end{array}$ & $\begin{array}{c}14.27 \pm .6 \\
-8.0 \% \\
P<0.06 \\
\mathrm{n}=7\end{array}$ \\
\hline & Day 40 & $\begin{array}{c}\text { Average score } \\
\% \text { change } \\
P \text {-value vs. Day } 0\end{array}$ & $\begin{array}{c}7.36 \pm .6 \\
2.3 \% \\
P<0.4 \mathrm{I} \\
\mathrm{n}=8\end{array}$ & $\begin{array}{c}32.17 \pm 2.0 \\
1.6 \% \\
P<0.38 \\
n=10\end{array}$ & $\begin{array}{c}10.27 \pm .9 \\
-7.0 \% \\
P<0.05 \\
\mathrm{n}=9\end{array}$ & $\begin{array}{c}|3.8| \pm .7 \\
-|| .0 \% \\
P<0.03 \\
n=8\end{array}$ \\
\hline & Day 60-75 & $\begin{array}{c}\text { Average score } \\
\% \text { change } \\
P \text {-value vs. Day } 0\end{array}$ & $\begin{array}{c}7.40 \pm .3 \\
2.9 \% \\
P<0.47 \\
\mathrm{n}=7\end{array}$ & $\begin{array}{c}32.10 \pm 1.1 \\
1.3 \% \\
P<0.32 \\
n=7\end{array}$ & $\begin{array}{c}10.99 \pm .5 \\
-0.0 \% \\
P<0.25 \\
\mathrm{n}=7\end{array}$ & $\begin{array}{c}14.9 \pm .6 \\
-4.0 \% \\
P<0.08 \\
n=7\end{array}$ \\
\hline \multirow[t]{4}{*}{ Treated } & Day 0 & $\begin{array}{c}\text { Average score } \\
\mathrm{n}\end{array}$ & $\begin{array}{c}6.16 \pm 0.3 \\
n=30\end{array}$ & $\begin{array}{c}27.59 \pm 1.1 \\
n=30\end{array}$ & $\begin{array}{c}9.65 \pm 0.7 \\
n=30\end{array}$ & $\begin{array}{c}14.73 \pm 0.2 \\
n=30\end{array}$ \\
\hline & Day 20 & $\begin{array}{c}\text { Average score } \\
\% \text { change } \\
P \text {-value vs. Day } 0\end{array}$ & $\begin{array}{c}6.71 \pm 0.3 \\
9.0 \% \\
P<0.001 \\
\mathrm{n}=29\end{array}$ & $\begin{array}{c}30.46 \pm 1.1 \\
\quad 10.4 \% \\
P<0.0009 \\
n=29\end{array}$ & $\begin{array}{c}10.11 \pm 0.4 \\
4.7 \% \\
P<0.22 \\
\mathrm{n}=29\end{array}$ & $\begin{array}{l}15.22 \pm 0.3 \\
\quad 3.3 \% \\
P<0.003 \\
\mathrm{n}=29\end{array}$ \\
\hline & Day 40 & $\begin{array}{c}\text { Average score } \\
\% \text { change } \\
P \text {-value vs. Day } 0\end{array}$ & $\begin{array}{c}6.35 \pm 0.3 \\
3.2 \% \\
P<0.06 \\
\mathrm{n}=26\end{array}$ & $\begin{array}{c}28.23 \pm 1.1 \\
2.3 \% \\
P<0.16 \\
n=26\end{array}$ & $\begin{array}{c}9.65 \pm 0.3 \\
-0.07 \% \\
P<0.47 \\
n=26\end{array}$ & $\begin{array}{c}15.32 \pm 0.3 \\
4.0 \% \\
P<0.001 \\
n=26\end{array}$ \\
\hline & Day 60-75 & $\begin{array}{c}\text { Average score } \\
\% \text { change } \\
P \text {-value vs. Day } 0\end{array}$ & $\begin{array}{c}6.42 \pm 0.4 \\
4.3 \% \\
P<0.02 \\
n=19\end{array}$ & $\begin{array}{c}29.18 \pm 1.3 \\
5.7 \% \\
P<0.03 \\
n=20\end{array}$ & $\begin{array}{c}9.82 \pm 0.5 \\
1.6 \% \\
P<0.002 \\
n=19\end{array}$ & $\begin{array}{c}15.46 \pm 0.4 \\
4.9 \% \\
P<0.004 \\
n=19\end{array}$ \\
\hline
\end{tabular}

Hematological parameters are significantly improved with plasmid treatment compared to day 0 . For cats normal RBC $5.7-10.5 \times 106 / \mathrm{mm}^{3} ;$ normal $\mathrm{Ht}$ 38-52\%; and normal $\mathrm{Hb} 9-16 \mathrm{~g} / \mathrm{dl}$.

lactated Ringer's solution, saline, Normasol) or by specialized diet. If fitting the inclusion criteria, owners were offered to have their pets receive the GHRH-treatment or serve as controls in the study. Controls were maintained on the standard of care therapy (fluids and diet) throughout the study period. All animals were enrolled within a 6 months period (November to May). Dogs were treated with a dog-specific GHRH-expressing plasmid on average $288.86 \pm 90.34$ days after initial diagnosis of CRF, while cats were treated with a cat-specific GHRH-expressing plasmid $255.60 \pm 61.26$ days after diagnosis. The condition of inclusion in our study was an estimated survival of at least 20 days post-treatment (in order to allow for plasmid activation and expression of GHRH from the skeletal muscle) when a second blood draw could be made. The animals were weighed and bled before treatment and at days 20, 40, and 75 post-injection. At each time point, complete $\mathrm{CBC}$ and metabolic profiles were assessed by the same independent laboratory (Antech Diagnostics, Irvine, CA). Wellness forms were requested to be completed by owners at each visit. Body weight, activity level, exercise tolerance, mentation (attitude, alertness), appetite, thirst, frequency of urination, number of bowel movements, fre- quency of diarrhea, frequency of vomiting, and overall quality of life were assessed with ratings of their pets condition as significantly increased (5), increased (4), no change (3), decreased (2) or significantly decreased (1).

Case-matched control dogs $(12.90 \pm 0.59$ years, $25.49 \pm$ $9.04 \mathrm{~kg})$ and cats $(13.33 \pm 0.87$ years, $10.44 \pm 1.48 \mathrm{~kg})$ (those who's owners were offered, but did not wish to have their pets treated with the GHRH-expressing plasmid $+\mathrm{EP}$, and thus not receiving plasmid but standard renal failure treatment, such as subcutaneous fluids when necessary and specialized diet) identified suitable for inclusion into the study by the attending veterinarian, were evaluated for parameters that enter into the standard of care; due to the deteriorating general state of control animals, the number of blood draws and quantity of blood per draw was maintained to a minimum in these animals in agreement with standard veterinary practice (i.e. hematology and biochemistry parameters were evaluated, while hormonal or other supplementary assays, such as iron or IGF-I concentrations were not performed on these group). For these parameters, baseline values were used for comparison in the GHRH-treated group. 


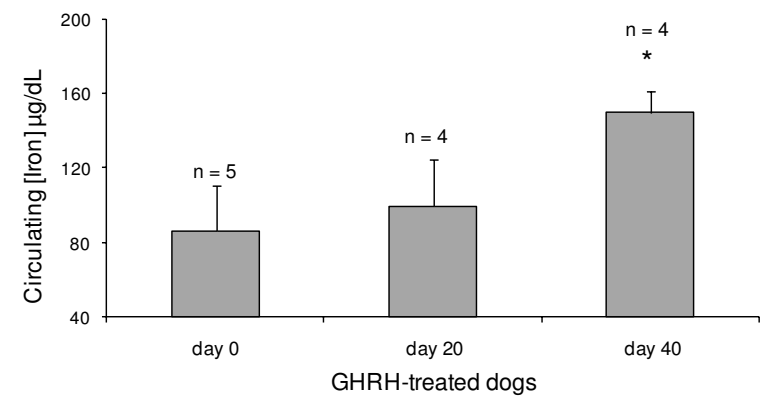

Figure 2

Circulating iron concentration in GHRH-treated dogs. The results are presented as means \pm SEM. Circulating iron concentration is significantly improved in dogs treated with plasmid-mediated GHRH (where $* P<0.05$ ).

\section{Kidney Failure Dogs}

Thirty dogs with kidney failure were used in this GHRH study (Table 1) with twelve additional dogs for controls. Creatinine levels had to be at least $2.5 \mathrm{mg} / \mathrm{dl}$ (normal range: $0.4-1.8 \mathrm{mg} / \mathrm{dl}$ ) and blood urea nitrogen at least 35 $\mathrm{mg} / \mathrm{dl}$ (normal range: $7-27 \mathrm{mg} / \mathrm{dl}$ ) for the animal to be enrolled in the study. The average age of the dogs was 13.1 \pm 0.56 years. The dogs were injected with $0.4 \mathrm{mg}$ of a dog specific GHRH expressing plasmid, pSP-dog-GHRH.

\section{Kidney Failure Cats}

Thirty cats with kidney failure were used in GHRH studies (Table 1) with fifteen additional cats as controls. Creati-

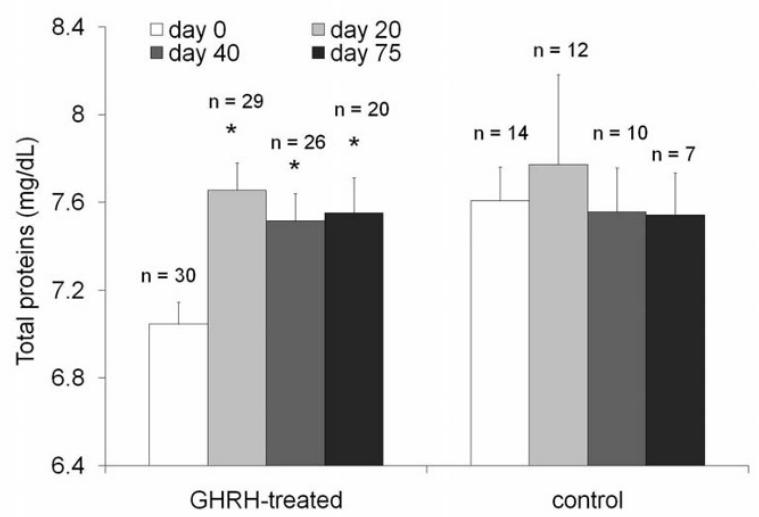

Figure 3

Protein metabolism in cats with chronic renal failure treated with plasmid-mediated GHRH therapy. The results are presented as means \pm SEM. Protein metabolism is significantly improved in cats treated with plasmid-mediated GHRH (where * $P<0.05$ ) whereas control cats do not show any significant differences over the time points measured. nine levels had to be at least $3.5 \mathrm{mg} / \mathrm{dl}$ (normal range: $0.8-2.3 \mathrm{mg} / \mathrm{dl}$ ) and blood urea nitrogen had to be at least $45 \mathrm{mg} / \mathrm{dl}$ (normal range: $13.4-32.5 \mathrm{mg} / \mathrm{dl}$ ) for the animal to be enrolled in the study. The average age of the cats was $13.2 \pm 0.66$ years. The cats were injected with $0.1 \mathrm{mg}$ of a cat-specific expressing plasmid pSP-cat-GHRH.

\section{DNA Constructs}

The plasmid pSPc5-12-GHRH contains a 360-bp SPc5-12 synthetic promoter [48]. The cat and dog-GHRH cDNA was cloned in our laboratory [49]; the transgene was synthetically produced and sub-cloned into a synthetic plasmid previously described [49]. The dog-specific GHRH expressing plasmid and cat-specific GHRH expressing plasmid, for dogs and cats, respectively, were used in these studies. Plasmids were prepared by batch fermentation followed by membrane chromatography purification. The endotoxin concentration was measured with Limulus Amebocyte Lysate (LAL) kinetic chromogenic assay, and the A405 of samples were recorded with SpectraMAX PLUS 384 Microplate Reader after a period of one hour incubation at $37^{\circ} \mathrm{C}$. The endotoxin levels for both preparations were less than $2 \mathrm{EU} / \mathrm{mg}$ of plasmid.

\section{Intramuscular injection with electroporation of plasmid DNA in canine or feline subjects with kidney failure}

Endotoxin-free plasmid preparation of species-specific pSP-GHRH was diluted in sterile water for injection to 2 $\mathrm{mg} / \mathrm{mL}$, and low molecular weight poly-L-glutamate (LGS) sodium salt solution was added to $1 \% \mathrm{w} / \mathrm{w}$. Dogs and cats in this study were anesthetized with isofluorane (5\% for induction, 2\% for maintenance). While anesthetized, plasmid was injected directly into the semitendinosus muscle. The injection was followed by constant current EP (CELLECTRA ${ }^{\circledR}$ device, VGX Pharmaceuticals Inc., The Woodlands, Texas) at 0.5 Amps, 3 pulses of 52 milliseconds each, 1 second between pulses with an IM applicator consisting of $1.375 \pm 0.020$ inch long 21 -gauge needles in a pentagonal arrangement [50]. Animals were allowed to recover from the anesthesia before rejoining their owners. Control animals underwent the EP procedure but were not injected with the GHRH-plasmid.

\section{Body Weight, Blood and Urine values}

Animals were weighed before the plasmid injection and at three post-treatment time points post-injection/EP using the same calibrated scale. One pre-injection/EP blood draw (day 0), and three post-treatment draws (at approximately days $20,40,75$ ) were performed. Blood and urine samples, obtained by standard veterinarian practice, were analyzed for biochemistry, metabolism and hormones. Complete blood count (CBC), biochemistry and hormone values for day 0 served as baseline reference for each dog or cat. Whole blood was collected in Monoject ${ }^{\circledast}$ Lavender Stopper blood collection tubes with $3.0 \mathrm{mg}$ EDTA 

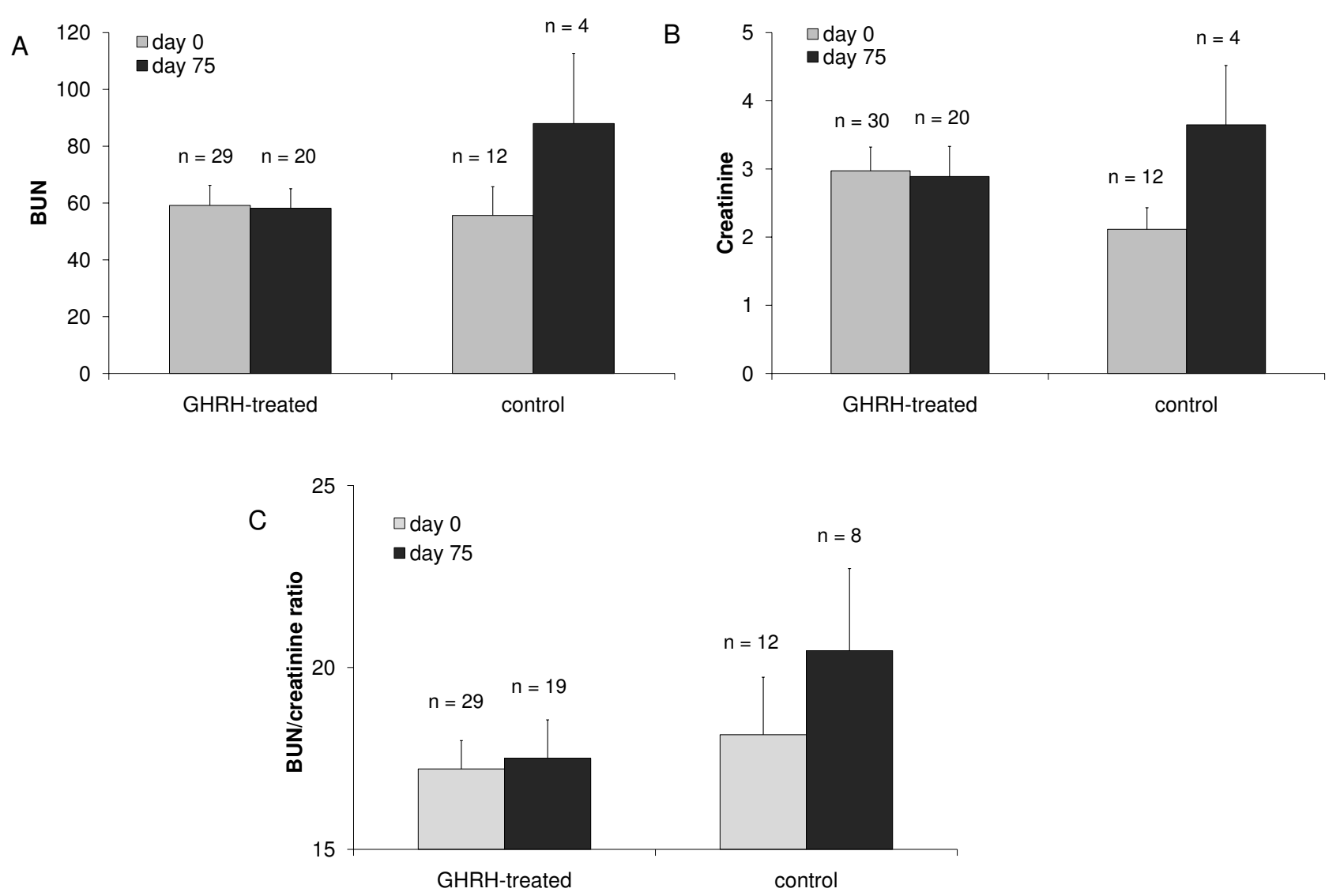

Figure 4

BUN and Creatinine levels and ratio for GHRH-treated dogs and cats. The results are presented as means \pm SEM. The BUN (A) and creatinine (B) levels remained unchanged for the GHRH-treated dogs while control animals displayed an increase in BUN and creatinine at 75 days compared to day 0 . (C) The BUN/creatinine ratio in cats was not significantly altered in the GHRH-treated animals but control cats showed an increase at day 75 compared to day 0.

(Sherwood Medical, St. Louis, MO) and submitted for CBC analysis (Antech Diagnostics, Irvine, CA). Serum was aliquoted for radioimmunoassay and biochemical analysis (Antech Diagnostics, Irvine, CA).

\section{Plasma IGF-I}

IGF-I levels were not determined in control animals as there were too few blood samples to warrant statistical testing (as only a small number of animals survived to the end of the study); IGF-I levels were measured in treated dogs and cats throughout the study and compared to baseline values. IGF-I levels were measured by heterologous human radioimmunometric assay from collected blood samples (Diagnostic System Lab., Webster, TX). The sensitivity of the assay was $0.8 \mathrm{ng} / \mathrm{ml}$; intra-assay and inter-assay variation was $3.4 \%$ and $4.5 \%$ respectively. All samples were analyzed in the same assay and the intraassay variability was $4.2 \%$.

\section{Statistics}

A Microsoft Excel statistics analysis package was used. Values shown in the Figures are the mean \pm SEM. Specific $P$ values were obtained by comparison using ANOVA. $P<$ 0.05 was set as the level of statistical significance.

\section{Abbreviations}

GHRH: growth hormone-releasing hormone; GH: growth hormone; IGF-I: insulin-like growth factor-I; CRF: chronic renal failure; EP: electroporation; QOL: quality of life; PVC: hematocrit; Hb: hemoglobin; RBC: red blood cell; MHC: mean red blood cell hemoglobin.

\section{Authors' contributions}

$\mathrm{PB}$ participated in the design of the study, helped with electroporation and collected samples. RD conceived of the plasmid design, the study, and participated in its design and coordination and helped to draft the manu- 
script. AB drafted the manuscript. MP helped collect samples and carried out the immunoassays. MP participated in the construct design. All authors read and approved the final manuscript.

\section{Acknowledgements}

We thank the dogs and cats and their owners for their participation and cooperation in this study. We thank the clinical staff at all the participating veterinary clinics for their excellent patient care, especially veterinarians M.A. Crist, Deb Cunningham, Cory Stiles, David Wulf, Cynthia Rigoni, G.M. Hadash, Stephen Fronefield, Ben Tharp, Sharon Kiker, J.W. Whitmore, Gary Lackey, Agnes Rupley, and Nielesh Narurkar. This study was funded by VGX Pharmaceuticals Inc. (formerly ADViSYS), The Woodlands, Texas.

\section{References}

I. Al Suwaidi J, Reddan DN, Williams K, Pieper KS, Harrington RA, Califf RM, et al.: Prognostic implications of abnormalities in renal function in patients with acute coronary syndromes. Circulation 2002, 106:974-980.

2. Nampoory MR, Johny KV, Costandi JN, Gupta RK, Nair MP, Samhan $M$, et al:: Inferior long-term outcome of renal transplantation in patients with diabetes mellitus. Med Princ Pract 2002 I I:29-34.

3. Weiner DE: Causes and consequences of chronic kidney disease: implications for managed health care. J Manag Care Pharm 2007, 13:SI-S9.

4. Crook ED, Washington DO, Flack JM: Screening and prevention of chronic kidney disease. I Natl Med Assoc 2002, 94:55S-62S.

5. Mak RH, Cheung WW, Roberts CT Jr: The growth hormoneinsulin-like growth factor-I axis in chronic kidney disease. Growth Horm IGF Res 2007, 18:17-25.

6. Mahesh S, Kaskel F: Growth hormone axis in chronic kidney disease. Pediatr Nephrol 2007, 23:4 I-48.

7. Clark RG: Recombinant insulin-like growth factor-I as a therapy for IGF-I deficiency in renal failure. Pediatr Nephrol 2005, 20:290-294.

8. Seikaly MG, Salhab N, Warady BA, Stablein D: Use of rhGH in children with chronic kidney disease: lessons from NAPRTCS. Pediatr Nephrol 2007, 22: I 195- 1204.

9. Wuhl E, Schaefer F: Effects of growth hormone in patients with chronic renal failure: experience in children and adults. Horm Res 2002, 58(Suppl 3):35-38.

10. Tone CM, Cardoza DM, Carpenter RH, Draghia-Akli R: Long-term effects of plasmid-mediated growth hormone releasing hormone in dogs. Cancer Gene Ther 2004, II:389-396.

II. Brown PA, Davis WC, Draghia-Akli R: Immune enhancing effects of growth hormone releasing hormone delivered by plasmid injection and electroporation. Molecular Therapy 2004, 10:644-65I.

12. Brown PA, Bodles-Brakhop A, Draghia-Akli R: Plasmid growth hormone releasing hormone therapy in healthy and laminitis-afflicted horses-evaluation and pilot study. J Gene Med 2008, 10:564-574.

13. Bodles-Brakhop AM, Brown PA, Pope MA, Draghia-Akli R: Doubleblinded, Placebo-controlled Plasmid GHRH Trial for Cancer-associated Anemia in Dogs. Mol Ther 2008, 16:862-870.

14. Scheerlinck JP, Karlis J, Tjelle TE, Presidente PJ, Mathiesen I, Newton SE: In vivo electroporation improves immune responses to DNA vaccination in sheep. Vaccine 2004, 22:1820-1825.

15. Tjelle TE, Salte R, Mathiesen I, Kjeken R: A novel electroporation device for gene delivery in large animals and humans. Vaccine 2006, 24:4667-4670.

16. van Drunen Littel-van den Hurk, Luxembourg A, Ellefsen B, Wilson D, Ubach A, Hannaman D, et al:: Electroporation-based DNA transfer enhances gene expression and immune responses to DNA vaccines in cattle. Vaccine 2008, 26:5503-5509.

17. Bergman PJ, McKnight J, Novosad A, Charney S, Farrelly J, Craft D, et al.: Long-term survival of dogs with advanced malignant melanoma after DNA vaccination with xenogeneic human tyrosinase: a phase I trial. Clin Cancer Res 2003, 9: | 284-I 290.

18. Kopyt N: Management and treatment of chronic kidney disease. Nurse Pract 2007, 32:14-23.
19. O'Sullivan AJ, Lawson JA, Chan M, Kelly Jl: Body composition and energy metabolism in chronic renal insufficiency. Am J Kidney Dis 2002, 39:369-375.

20. Robinson B, Artz AS, Culleton B, Critchlow C, Sciarra A, Audhya P. Prevalence of anemia in the nursing home: contribution of chronic kidney disease. J Am Geriatr Soc 2007, 55: I566-I570.

21. Rubin SI: Chronic renal failure and its management and nephrolithiasis. Vet Clin North Am Small Anim Pract 1997, 27:1331-1354.

22. Levin A: Identification of patients and risk factors in chronic kidney disease - evaluating risk factors and therapeutic strategies. Nephrol Dial Transplant 200I, I6(Suppl 7):57-60.

23. Elliott DA: Nutritional management of chronic renal disease in dogs and cats. Vet Clin North Am Small Anim Pract 2006, 36:1377-84.

24. Khorram $O$, Yeung $M, V u$ L, Yen SS: Effects of [norleucine27]growth hormone-releasing hormone (GHRH) (I-29)-NH2 administration on the immune system of aging men and women. I Clin Endocrinol Metab 1997, 82:3590-3596.

25. Bergamaschi S, Giavoli C, Ferrante E, Lania A, Rusconi R, Spada A, et al.: Growth hormone replacement therapy in growth hormone deficient children and adults: Effects on hemochrome. J Endocrinol lnvest 2006, 29:399-404.

26. Deicher R, Horl WH: Hormonal adjuvants for the treatment of renal anaemia. Eur J Clin Invest 2005, 35(Suppl 3):75-84

27. Randolph JE, Scarlett J, Stokol T, MacLeod JN: Clinical efficacy and safety of recombinant canine erythropoietin in dogs with anemia of chronic renal failure and dogs with recombinant human erythropoietin-induced red cell aplasia. J Vet Intern Med 2004, I 8:8I-9I.

28. Randolph JE, Scarlett JM, Stokol T, Saunders KM, MacLeod JN: Expression, bioactivity, and clinical assessment of recombinant feline erythropoietin. Am J Vet Res 2004, 65: I355-1366.

29. Gotloib L, Silverberg D, Fudin R, Shostak A: Iron deficiency is a common cause of anemia in chronic kidney disease and can often be corrected with intravenous iron. J Nephrol 2006, 19:16I-167.

30. Horl WH: Iron therapy for renal anemia: how much needed, how much harmful? Pediatr Nephrol 2007, 22:480-489.

31. Brearley C, Priestley A, Leighton-Scott J, Christen M: Pharmacokinetics of recombinant human growth hormone administered by cool.click 2, a new needle-free device, compared with subcutaneous administration using a conventional syringe and needle. BMC Clin Pharmacol 2007, 7:10.

32. Prud'homme G], Glinka Y, Khan AS, Draghia-Akli R: Electroporation-enhanced nonviral gene transfer for the prevention or treatment of immunological, endocrine and neoplastic diseases. Curr Gene Ther 2006, 6:243-273.

33. Luxembourg A, Evans CF, Hannaman D: Electroporation-based DNA immunisation: translation to the clinic. Expert Opin Bio Ther 2007, 7:1647-1664.

34. Miyazaki S, Miyazaki J: In vivo DNA electrotransfer into muscle. Dev Growth Differ 2008, 50:479-483.

35. Aihara H, Miyazaki J: Gene transfer into muscle by electroporation in vivo. Nat Biotechnol 1998, 16:867-870.

36. Cemazar M, Golzio M, Sersa G, Rols MP, Teissie J: Electricallyassisted nucleic acids delivery to tissues in vivo: where do we stand? Curr Pharm Des 2006, I 2:3817-3825.

37. Roos AK, Moreno S, Leder C, Pavlenko M, King A, Pisa P: Enhancement of cellular immune response to a prostate cancer DNA vaccine by intradermal electroporation. Mol Ther 2006, 13:320-327.

38. Khan AS, Fiorotto ML, Cummings KK, Pope MA, Brown PA, DraghiaAkli R: Maternal GHRH plasmid administration changes pituitary cell lineage and improves progeny growth of pigs. Am J Physiol Endocrinol Metab 2003, 285:E224-E23I.

39. Bodles-Brakhop AM, Draghia-Akli R: DNA vaccination and gene therapy: optimization and delivery for cancer therapy. Expert Rev Vaccines 2008, 7:1085-I I0I.

40. Rice J, Ottensmeier $\mathrm{CH}$, Stevenson FK: DNA vaccines: precision tools for activating effective immunity against cancer. Nat Rev Cancer 2008, 8: 108-120.

4I. Kutzler MA, Weiner DB: DNA vaccines: ready for prime time? Nat Rev Genet 2008, 9:776-788.

42. Ng T, Marx G, Littlewood T, Macdougall I: Recombinant erythropoietin in clinical practice. Postgrad Med J 2003, 79:367-376. 
43. Lu X, Zhou A, Jin C: [The effects of electroporation-mediated erythropoietin (EPO) gene transfer into skeleton muscle on renal anemia]. Zhonghua Yi Xue Za Zhi 2000, 80:222-225.

44. Ataka K, Maruyama H, Neichi T, Miyazaki J, Gejyo F: Effects of erythropoietin-gene electrotransfer in rats with adenineinduced renal failure. Am J Nephrol 2003, 23:3 I5-323.

45. Fattori E, Cappelletti M, Zampaglione I, Mennuni C, Calvaruso F, Arcuri M, et al.: Gene electro-transfer of an improved erythropoietin plasmid in mice and non-human primates. J Gene Med 2005, 7:228-236.

46. Gao G, Lebherz C, Weiner DJ, Grant R, Calcedo R, McCullough B, et al.: Erythropoietin gene therapy leads to autoimmune anemia in macaques. Blood 2004, 103:3300-3302.

47. Draghia-Akli R, Ellis KM, Hill LA, Malone PB, Fiorotto ML: High-efficiency growth hormone releasing hormone plasmid vector administration into skeletal muscle mediated by electroporation in pigs. FASEB J 2003, 17:526-528.

48. Li X, Eastman EM, Schwartz RJ, Draghia-Akli R: Synthetic muscle promoters: activities exceeding naturally occurring regulatory sequences. Nat Biotechnol 1999, 17:24I-245.

49. Khan AS, Brown PA, Draghia-Akli R: Plasmid-based growth hormone releasing hormone supplementation and its applications. Current Opinion in Molecular Therapeutics 2005, 7:306-316.

50. Khan AS, Smith LC, Abruzzese RV, Cummings KK, Pope MA, Brown PA, et al.: Optimization of electroporation parameters for the intramuscular delivery of plasmids in pigs. DNA Cell Biol 2003, 22:807-8I4.

Publish with Bio Med Central and every scientist can read your work free of charge

"BioMed Central will be the most significant development for disseminating the results of biomedical research in our lifetime."

Sir Paul Nurse, Cancer Research UK

Your research papers will be:

- available free of charge to the entire biomedical community

- peer reviewed and published immediately upon acceptance

- cited in PubMed and archived on PubMed Central

- yours - you keep the copyright

Submit your manuscript here:

http://www.biomedcentral.com/info/publishing_adv.asp
BioMedcentral 